Mandelstam, J. (1954). J. gen. Microbiol. 11, 426-437.

\title{
Induced Biosynthesis of Lysine Decarboxylase in Bacterium cadaveris
}

\author{
BY J. MANDELSTAM
}

National Institute for Medical Research, Mill Hill, London, N.W. 7

\begin{abstract}
SUMMARY : Experiments have been carried out on the kinetics of induced synthesis of lysine decarboxylase in washed suspensions of Bacterium cadaveris. The enzyme is produced when glucose and lysine are present simultaneously. Lysine analogues tested as inducers were inactive. In anaerobic synthesis the rate of formation of new enzyme is directly proportional to the degree of saturation of the enzyme by its substrate; in aerobic synthesis a maximal rate is found even when the enzyme is almost totally unsaturated. The $\mathrm{pH}$ curve for enzyme synthesis corresponds closely with that for enzyme activity. Adapted cells undergo de-adaptation when incubated with glucose in the absence of lysine; this is due to the effect of cadaverine on the co-enzyme. The bearing of these results on current theories of enzyme induction is discussed.
\end{abstract}

In experiments previously reported, induced enzyme synthesis in yeast was examined from the standpoint of the 'mass action theory of enzyme adaptation' (Mandelstam \& Yudkin, 1952). According to this theory, the inducible enzyme is in equilibrium with a precursor; addition of the substrate, or other inducer, upsets the equilibrium which is then restored by further enzyme synthesis (Yudkin, 1938). The postulates are simple and the theory can be readily expressed in quantitative terms (Mandelstam, 1952). It was found that when cells were adapted to galactose and maltose, the results were in close agreement with the qualitative and quantitative predictions made.

Although the theory thus appears to hold for these enzymes in yeast it is in conflict with observations made on other systems. For instance, Monod, Cohen-Bazire $\&$ Cohn (1951) showed that for $\beta$-galactosidase synthesis in Escherichia coli there was no correlation between inductive activity and affinity for the enzyme. Similarly, penicillinase formation in Bacillus cereus can be induced by minute amounts of penicillin and the process continues at an undiminished rate in the absence of any detectable free substrate (Pollock, 1950). It seems that in this case, and in that of $\beta$-galactosidase, the inducer acts by combining with something other than the enzyme, and that the complex thus formed catalyses the synthesis of the enzyme. This can be schematically represented as follows:

$$
\begin{gathered}
\mathbf{I}+\mathbf{R} \\
\mathbb{1} \\
\mathbf{I R} \\
\mathbf{B}--\rightarrow \mathrm{E}
\end{gathered}
$$

$\mathbf{B}$ is a precursor or pool of precursors, $\mathbf{E}$ is the enzyme, $\mathbf{I}$ the inducer, $\mathbf{R}$ the receptor and IR is the complex which catalyses the synthesis of $\mathbf{E}$. The 


\section{Biosynthesis of lysine decarboxylase}

broken arrow indicates that a number of reactions may be involved. (In the case of penicillin the reaction with the receptor seems to be irreversible.)

The 'catalyst' theory may be compared with the 'mass action' theory:

$$
\mathrm{B} \rightleftharpoons \mathrm{E}+\mathrm{I} \rightleftharpoons \mathrm{EI} \text {. }
$$

Addition of inducer I upsets the equilibrium between the enzyme $\mathbf{E}$ and the pool of precursors $\mathbf{B}$, and the system adjusts itself by producing more enzyme. It follows that the initial rate at which enzyme is synthesized will be proportional to the degree of saturation of $\mathrm{E}$. On the other hand, if the 'catalyst' theory holds, the rate of synthesis will depend on the degree of saturation of $\mathbf{R}$. A kinetic study of enzyme production might be expected to provide evidence for differentiating between the two mechanisms, unless $\mathbf{R}$ and $\mathbf{E}$ happened to to have the same affinity for the inducer.

The system chosen for investigation was lysine decarboxylase in Bacterium cadaveris, because only one enzyme is involved; and because the cells do not depend on the inducing substrate for their supply of energy.

\section{MATERIALS AND METHODS}

The organism used was Bacterium cadaveris (NCTC 6578). The growth medium contained: $\mathrm{KH}_{2} \mathrm{PO}_{4}, 4.5 \mathrm{~g}$.; $\mathrm{NH}_{4} \mathrm{Cl}, 0.5 \mathrm{~g}$.; $\left(\mathrm{NH}_{4}\right)_{2} \mathrm{SO}_{4}, 0.5$ g.; $\mathrm{MgSO}_{4}, 20 \mathrm{mg}$; $\mathrm{Fe}\left(\mathrm{NH}_{4}\right)_{2}\left(\mathrm{SO}_{4}\right)_{2}, 15.6 \mathrm{mg}$.; glucose, $20 \mathrm{~g}$.; sodium lactate, $20 \mathrm{~g}$.; and water to 11 . The $\mathrm{pH}$ value was adjusted to $7 \cdot 5$ and the organisms grown with shaking at $35^{\circ}$ for $18 \mathrm{hr}$., by which time growth was approaching the end of the logarithmic phase and the culture contained about 0.9-1.0 mg. dry weight bacteria $/ \mathrm{ml}$.

Enzyme induction. Unless otherwise stated, enzyme induction and assay, and the washing of bacteria were carried out in $0.05 \mathrm{M}$-phthalate buffer at $\mathrm{pH} \mathrm{5 \cdot 5.} \mathrm{For} \mathrm{induction,} \mathrm{the} \mathrm{cells} \mathrm{were} \mathrm{incubated} \mathrm{at} 30^{\circ}$ with $1 \%$ glucose and lysine of varying concentrations (see below). The bacterial density was $0 \cdot 15 \mathrm{mg}$. dry weight bacteria $/ \mathrm{ml}$. Five $\mathrm{ml}$. samples were removed at intervals and added to $1 \mathrm{ml}$. of $10^{-3} \mathrm{M}$-sodium azide. This concentration of azide was sufficient to prevent any further induction but had no inhibitory effect on formed enzyme. The cells were then washed and resuspended in $5 \mathrm{ml}$. of buffer solution and $2.5 \mathrm{ml}$. taken for assay. Activity was measured anaerobically in Warburg manometers at $30^{\circ}$ using $0.5 \mathrm{ml}$. of $0.067 \mathrm{M}$-lysine in the sidearms. For estimation of the apo-enzyme, the cells were shaken with a drop of toluene and left at room temperature for $20 \mathrm{~min}$.; the toluene was then removed by a slow stream of air and the activity measured in the presence of pyridoxal phosphate $(\mathbf{1 2 . 5} \mu \mathrm{g} . / \mathrm{ml}$.). The toluene treatment was found to be essential because pyridoxal phosphate fails to penetrate untreated cells. Carbon dioxide production was somewhat erratic during the first 5 min., but steady readings were obtained for the next $20 \mathrm{~min}$. The $\mathrm{CO}_{2}$ evolved under these conditions was proportional to the enzyme present. Enzyme activity is expressed in arbitrary units $\left(\mu \mathrm{l} . \mathrm{CO}_{2} / 20 \mathrm{~min}\right.$.). Bacterial concentrations were determined by opacity measurements using a Spekker absorptiometer with filter 508, and a calibration curve of opacity against dry weight $/ \mathrm{ml}$. 
Special reagents. Cadaverine was prepared by the action of hydrazoic acid on pimelic acid (Oesterlin, 1932); the picrate was isolated and recrystallized from hot water, and the dihydrochloride prepared from it in the normal way. L- $\epsilon-N$-benzoyl-lysine and L- $\epsilon-N$-acetyllysine were prepared from L-lysine by the methods of Sanger (1946) and Neuberger \& Sanger (1943). DL- $\epsilon$-hydroxy$\alpha$-aminocaproic acid was synthesized from dihydropyran (Gaudry, 1948). $\alpha-\epsilon$-Diaminoheptanoic acid was prepared from $O$-methylcyclohexanone via $\epsilon$ - $N$-benzoyl-aminoheptanoic acid (method of McLaren \& Knight, 1951), and subsequent chlorination, amination and hydrolysis carried out by the method of Galat (1947).

\section{RESULTS}

\section{Stability of lysine decarboxylase}

To begin with, it was necessary to examine the stability of lysine decarboxylase in view of Gale's statement (1940) that the amino acid decarboxylases may be markedly unstable even at $30^{\circ}$. It was found that there was no detectable loss of activity even after $3 \mathrm{hr}$., when cells were incubated in buffer at $30^{\circ}$. The fall in $\mathrm{CO}_{2}$ production commonly observed after the first half hour of manometric measurement was due to exhaustion of substrate. The initial rate of decarboxylation could be restored by resuspending the cells in fresh buffer or by adding more lysine from a second side arm.

\section{Conditions for induction of lysine decarboxylase in washed suspensions}

When washed cells were incubated with glucose and lysine $(0.011 \mathrm{M})$ at $30^{\circ}$ a linear rate of synthesis of lysine decarboxylase was found (Fig. 1). An exponential rate of increase was not observed under any of the conditions of induction tested. In aerobic induction there was a lag period of about $10 \mathrm{~min}$. (often much less) before the linear phase of enzyme production began; anaerobically there was no lag. L-Lysine and DL-lysine of equivalent concentration were equally effective, the $\mathrm{D}$-isomer having no apparent effect either as an inducer or as an inhibitor of induction. During induction there was no increase in cell mass as measured by opacity, nor was there any detectable alteration in the $\mathrm{pH}$. For adaptation to occur at all, it was necessary for glucose and lysine to be present simultaneously. No increase in activity was caused by treatment with glucose, either alone or in conjunction with ammonium salts, magnesium or ATP. When $\mathrm{NH}_{4} \mathrm{Cl}$ was added together with lysine and glucose the rate of increase of activity was not affected, but the final level was about $10 \%$ higher.

\section{The effect of $\mathrm{pH}$ on the rate of formation of enzyme}

Washed cells were incubated aerobically with glucose and lysine $(0 \cdot 11 \mathrm{M})$

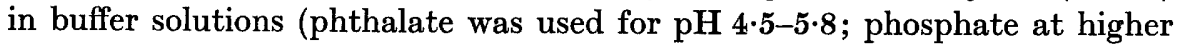
$\mathrm{pH}$ values, with overlap at $\mathrm{pH} 5 \cdot 8)$. Samples were taken at intervals during the first $90 \mathrm{~min}$. of incubation and added to the azide solution. The cells were washed and activity determined at $\mathrm{pH} 5.5$ in the usual way. The rate of increase of activity was measured by the slope of the line. Owing to the 
practical difficulty of doing more than three curves simultaneously, the following procedure was adopted to obtain a composite curve of adaptation against $\mathrm{pH}$ value. The rate at $\mathrm{pH} 5.5$ was arbitrarily taken as 100 and the rates at two other $\mathrm{pH}$ values expressed as fractions of this value. The final curve is shown in Fig. 2, together with the curve for enzyme activity. The latter was obtained by suspending washed cells in the appropriate buffer solutions and measuring $\mathrm{CO}_{2}$ production manometrically. Readings were corrected for $\mathrm{CO}_{2}$ retention.

It will be seen that the curve for enzyme synthesis follows very closely that for enzyme activity, and both are optimal at $\mathrm{pH} 5 \cdot 3-5 \cdot 6$. A similar curve was found when enzyme induction was carried out anaerobically. That this $\mathrm{pH}$ effect was an effect on the synthesis of the apo-enzyme was shown by estimating the activity in toluene-treated cells in the presence of pyridoxal phosphate. Higher absolute values were obtained but the relationship between the rates was unaffected.

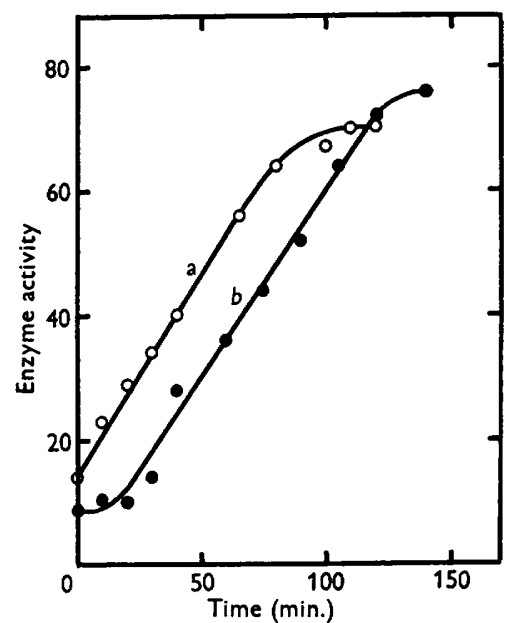

Fig. 1

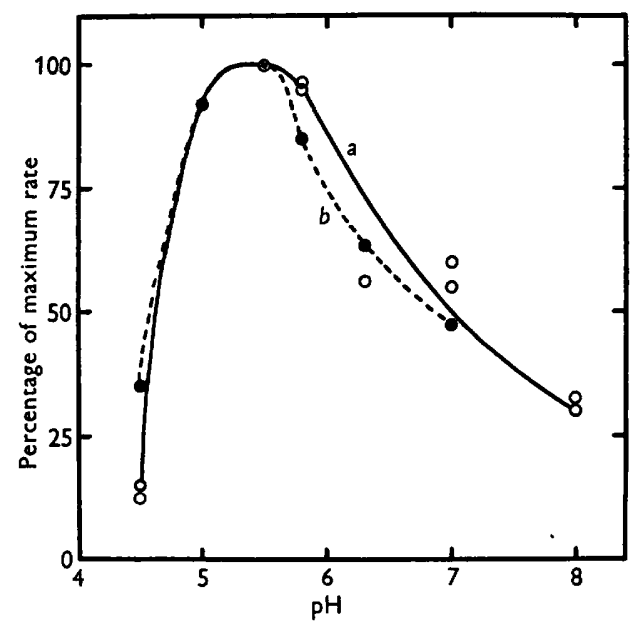

Fig. 2

Fig. 1. Induction of lysine decarboxylase activity in washed cell suspensions by incubation with lysine $(0.011 \mathrm{M})$ and glucose $(1 \%):(a)$ anaerobic induction; $(b)$ aerobic induction.

Fig. 2. Effect of $\mathrm{pH}$ on the rate of aerobic synthesis of lysine decarboxylase $(a)$ compared with the effect on the activity of the enzyme itself $(b)$.

The effect of concentration of lysine on the rate of formation of enzyme

Anaerobic induction. When cells were incubated with lysine and glucose in an atmosphere of nitrogen the rate of synthesis of the enzyme increased with the concentration of lysine (Fig. 3A) and was maximal at $0.022 \mathrm{M}$. To plot a composite curve, the slope of the line at $0.022 \mathrm{M}$ in each experiment was taken as 100 and the slopes at two other concentrations expressed as percentage fractions. The results of this experiment are shown as the points in Fig. 4. When plotted by the method of Dixon (1953) the points lie about a straight line. The value for $50 \%$ maximal rate of enzyme formation is $0.0013 \mathrm{M}$. 
For comparison the Michaelis constant for lysine decarboxylase was determined anaerobically using intact cells and a series of seven lysine concentrations over the range $0-0.022 \mathrm{M}$. The value found for $K_{m}$ was $0.0018 \mathrm{M}$. With intact cells in the presence of $1 \%$ glucose $K_{m}=0.0019-0.0020 \mathrm{M}$, while with acetone-dried preparations $K_{m}=0.0017 \mathrm{M}$. It is clear that glucose does not significantly affect the penetration of lysine into the cell. It is apparent that the rate of enzyme production is closely correlated with the degree of saturation by the substrate. This relationship was found to hold for the apo-enzyme as well as the activity of intact cells.

Aerobic induction. The effect of the concentration of lysine on the rate of enzyme formation was examined over the same range as before, but with the induction carried out aerobically. The results were markedly different (cf. Fig. 3A, B). The rate of synthesis was constant over the range tested, and the concentration of lysine could be further reduced to $10^{-4} \mathrm{M}$ without significantly affecting the initial rate.
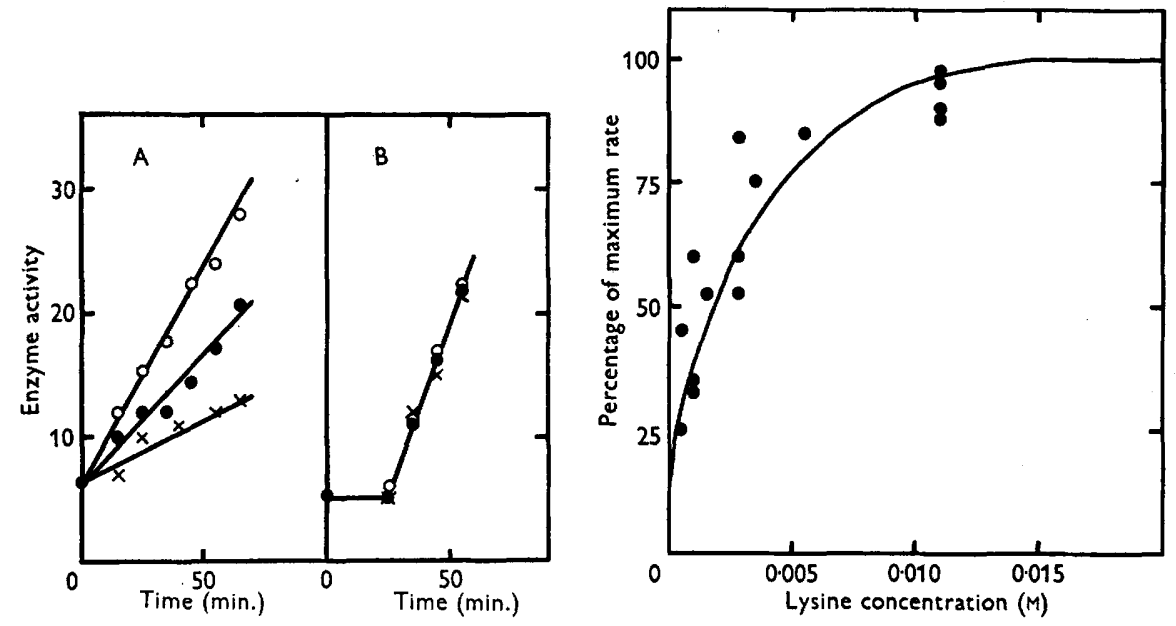

Fig. 3. Effect of lysine concentration on the rate of synthesis of enzyme anaerobically (A) and aerobically $(\mathbf{B})$.

Fig. 4. Effect of lysine concentration on the rate of anaerobic enzyme synthesis compared with the effect of lysine concentration on enzyme activity. The points give the rates of synthesis as a percentage of the rate at $0.022 \mathrm{M}$ lysine; the continuous curve is the saturation curve for lysine decarboxylase.

It thus appears that when the enzyme is induced aerobically its rate of appearance is maximal even at low concentrations of the inducer and is largely independent of the degree of saturation of the enzyme. The situation is similar to that found with $\beta$-galactosidase, and is consistent with a 'catalyst' mechanism. On the other hand, in anaerobic induction, the rate follows the saturation curve of the enzyme-a result anticipated on the basis of a 'mass action' mechanism. This apparent discrepancy might be explained in a number of ways:

(1) The enzyme is produced in both cases by a 'mass action' process; the 
aerobic induction appears to be discrepant because the cells concentrate lysine so that the enzyme is saturated even when the external concentration is low.

(2) The enzyme is produced ' catalytically' in both cases, but under anaerobic conditions the inducer is becoming rapidly exhausted.

(3) The enzyme is produced 'catalytically'; the anaerobic induction appears to be discrepant because the enzyme formed under these conditions is unstable but is stabilized by the substrate so that the amount of enzyme measured reflects the degree of saturation.

Experiments were then carried out to test these possibilities.

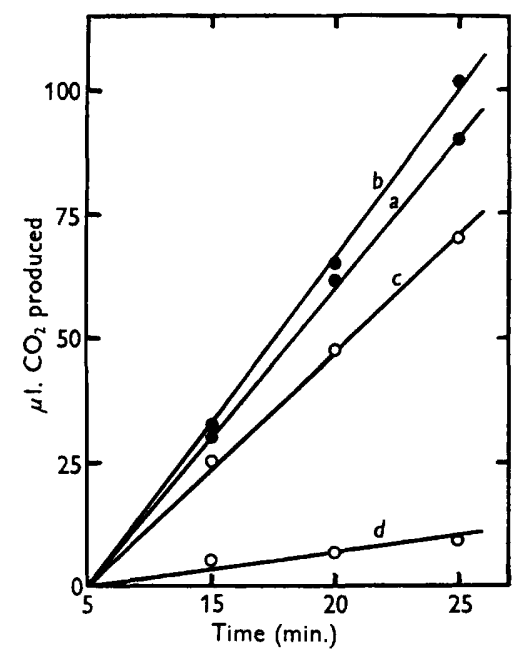

Fig. 5

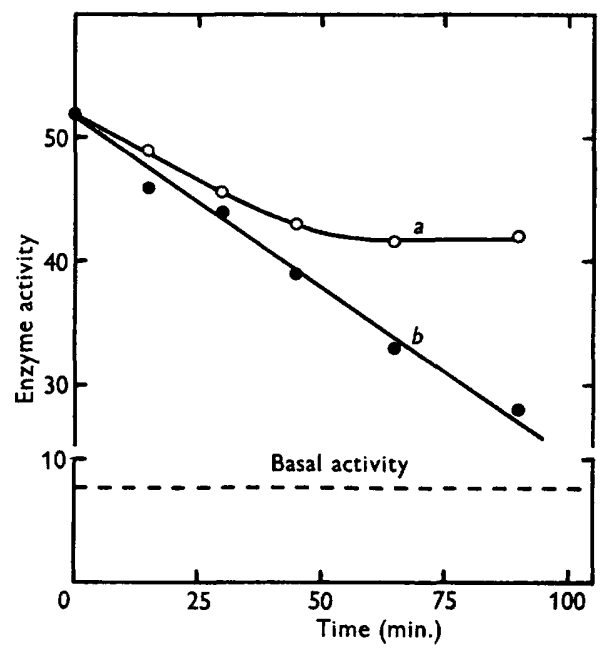

Fig. 6

Fig. 5. Effect of glucose on penetration of lysine into the cell: $(a)$ anaerobic decarboxylation of lysine; (b) anaerobic decarboxylation of lysine in presence of $1 \%$ glucose; (c) aerobic decarboxylation of lysine; $(d)$ aerobic decarboxylation of lysine in presence of $1 \%$ glucose. Values shown are corrected for 'blanks'. In presence of glucose, $\mathrm{CO}_{\mathbf{2}}$ production by 'blanks' anaerobically and aerobically, was $39 \mu \mathrm{l}$. and $-10 \mu 1 . / 30 \mathrm{~min}$. respectively.

Fig. 6. Loss of adaptive activity produced by incubating cells with glucose in the absence of lysine: (a) anaerobic incubation; (b) aerobic incubation. Activity measured on intact cells.

\section{(1) The effect of glucose on penetration of lysine into the cell}

To determine whether lysine was being concentrated in the cells under the experimental conditions for induction, a suspension of washed cells in buffer was placed in Warburg flasks with $0.5 \mathrm{ml}$. lysine solution or $0.5 \mathrm{ml} . \mathrm{H}_{2} \mathrm{O}$ (blanks) in the side-arms. A similar series of flasks contained glucose (final concentration $1 \%$ ). Production of $\mathrm{CO}_{2}$ was measured aerobically and anaerobically, the first $5 \mathrm{~min}$. being neglected. In the absence of glucose the rate of decarboxylation was slightly lower aerobically. In the presence of glucose, the aerobic decarboxylation was greatly retarded, while the anaerobic decarboxylation was, if anything, slightly increased (Fig. 5). A similar aerobic 
retardation due to glucose was found at all concentrations of lysine tested over the range of $0.0007 \mathrm{M}-0.011 \mathrm{M}$. This experiment makes the first possibility considered above untenable. It is apparent that under the conditions of aerobic induction, the lysine, far from being concentrated in the cell, actually fails to penetrate freely. A similar observation on the effect of glucose on the penetration of lysine was made by Gale (1947).

\section{(2) Utilization of lysine during induction}

The second possible explanation for the difference between aerobic and anaerobic induction was that, in the latter, the lysine was becoming rapidly exhausted. This possibility was tested as follows. Induction at two different concentrations of lysine was carried out in the usual way. At 60 min., measured samples were taken for lysine analysis and heated in boiling water for $15 \mathrm{~min}$. to destroy enzyme. The cells were removed by centrifuging, and the residual lysine in the supernatant fluid estimated manometrically using chloramine $\mathbf{T}$ (Cohen, 1940). As this method tends to give high values, a calibration curve had to be made using known concentrations of lysine. The results obtained in two experiments are shown in Table 1 . In the case of the more concentrated lysine solutions, the amount destroyed during induction was not significant, and even in the more dilute solutions $70-80 \%$ of the amount added was intact at the end of an hour. There is, therefore, no reason for assuming that the difference between aerobic and anaerobic induction is due to a rapid utilization of lysine under anaerobic conditions.

Table 1. Destruction of lysine during initial stages of anaerobic and aerobic induction of lysine decarboxylase

\begin{tabular}{|c|c|c|c|}
\hline $\begin{array}{l}\text { Conditions of } \\
\text { induction }\end{array}$ & $\begin{array}{l}\text { Initial lysine } \\
\text { concn. } \\
\text { (M) }\end{array}$ & $\begin{array}{l}\text { Lysine conen. } \\
\text { after } 1 \mathrm{hr} \text {. } \\
\text { (M) }\end{array}$ & $\begin{array}{c}\text { \% lysine } \\
\text { intact after } \\
1 \mathrm{hr} .\end{array}$ \\
\hline Anaerobic & 0.0111 & 0.0107 & 96.5 \\
\hline Aerobic & 0.0111 & 0.0112 & 100 \\
\hline Anaerobic & 0.00069 & $0 \cdot 00049$ & 71 \\
\hline Aerobic & 0.00069 & 0.00055 & 80 \\
\hline
\end{tabular}

\section{(3) Stability of lysine decarboxylase}

The following experiments were done to determine whether induced lysine decarboxylase was inherently unstable during induction and was stabilized by the substrate. The question of stability was examined from two points of view : the behaviour of the intact cells and the stability of the apo-enzyme.

Cells were incubated anaerobically with glucose and lysine. After $100 \mathrm{~min}$. they were centrifuged and resuspended, without washing, in the same volume of buffer containing glucose but no lysine. The suspension was divided into portions, one of which was incubated aerobically and the other in an atmosphere of nitrogen. Samples were taken periodically and the activity of the intact cells measured. In both suspensions there was a loss of activity which was more rapid in air (Fig. 6). It was also found that whether the induction 
had taken place aerobically or anaerobically there was no difference in the subsequent behaviour. Addition of lysine ( $0.01 \mathrm{M})$ to the system reversed the loss and, if added at the start, prevented it altogether.

Next, lysine-adapted cells were washed twice before being resuspended in buffer and glucose. This retarded the loss of activity and occasionally prevented it completely. However, loss of activity could be initiated by adding very small amounts of lysine (final concentration $3.3 \times 10^{-5} \mathrm{M}$ ).

In the light of these experiments it seemed that cadaverine, the endproduct of the reaction, might be the substance responsible for the deadaptation. To test this, adapted cells were washed and incubated aerobically with and without cadaverine $\left(10^{-4} \mathbf{M}\right)$ under various conditions. From Fig. 7 it will be seen that: $(a)$ in the control (glucose only) there was the usual slow fall in activity; $(b)$ this was greatly accelerated by cadaverine; $(c)$ cadaverine in the absence of glucose had no effect; $(d)$ sodium azide $\left(10^{-3} \mathrm{M}\right)$ stabilized the decarboxylase activity. It was found that cadaverine was active in small amounts and an effect was shown by solutions as dilute as $10^{-6} \mathbf{M}$. To determine whether this de-adaptation was due to loss of apo-enzyme or of co-factor, cells were adapted in the usual way, washed, and then de-adapted by incubation with glucose and cadaverine. Lysine decarboxylase activity was measured both in intact cells and in cells pre-treated with toluene; activity in the latter was measured in the presence of pyridoxal phosphate. It was found (Table 2) that the apo-enzyme is stable during the de-adaptation, and the loss of activity is presumably due to loss of the co-factor. This finding exhausts the last of the explanations considered for the differences between aerobic and anaerobic induction.

Table 2. Activity of intact cells compared with their apo-enzyme content during adaptation and de-adaptation

Cells were adapted by incubation with lysine and glucose, washed and de-adapted by treatment with glucose and cadaverine $\left(10^{-4} \mathrm{M}\right)$ for $100 \mathrm{~min}$.

$\begin{array}{lcc} & \text { Intact cells } & \text { Apo-enzyme } \\ \text { Basal activity: } & 4 & 3 \\ \text { Adapted: } & 47 & 122 \\ \text { De-adapted: } & 30 & 118\end{array}$

\section{Diamine oxidase}

Since the de-adaptation of the intact cells seemed to depend on active metabolism (requiring glucose and prevented by azide), it was considered that the phenomenon might be due to the induced formation of another enzyme, possibly diamine oxidase, by the cadaverine, with a consequent sharing of the cell's pyridoxal phosphate by the two enzymes. An attempt was made to see whether diamine oxidase formation could be induced by cadaverine, and, secondly, to examine the effect of some other substrates of diamine oxidase on adapted cells.

Washed cells were incubated with glucose and cadaverine $(0.005 \mathrm{M})$ at pH 5.5. Samples were taken at intervals during $2 \mathrm{hr}$. After washing, the cells

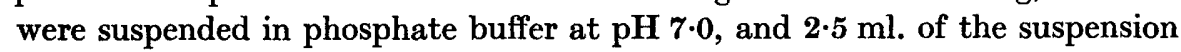


added to Warburg flasks. Cadaverine dihydrochloride $(0.5 \mathrm{ml}$. of $0.033 \mathrm{M}$ solution) was used as test substrate and oxygen uptake measured at $30^{\circ}$. The occurrence of oxidation could not be demonstrated in any of the samples even with $35 \mathrm{mg}$. dry weight of bacteria in the manometers.

Following this, the effect of putrescine and histamine (both $0.0005 \mathrm{M}$ ) on adapted cells was compared with that of cadaverine at the same concentration. Putrescine had an action similar to that of cadaverine while histamine was inactive (Fig. 8).

\section{Lysine analogues}

An attempt was made to find an inducer which was not attacked by the enzyme, so that the complication introduced by the production of cadaverine during induction would be avoided. The following compounds were tested both for ability to induce enzyme synthesis and ability to inhibit induction by lysine: L- $\epsilon$ - $N$-acetyllysine, L- $\epsilon-N$-benzoyllysine, $\alpha$-amino- $\epsilon$-hydroxycaproic acid and $\alpha-\epsilon$-diaminoheptanoic acid. The two last were synthetic products and the optical isomers had not been resolved. All these compounds were inactive.

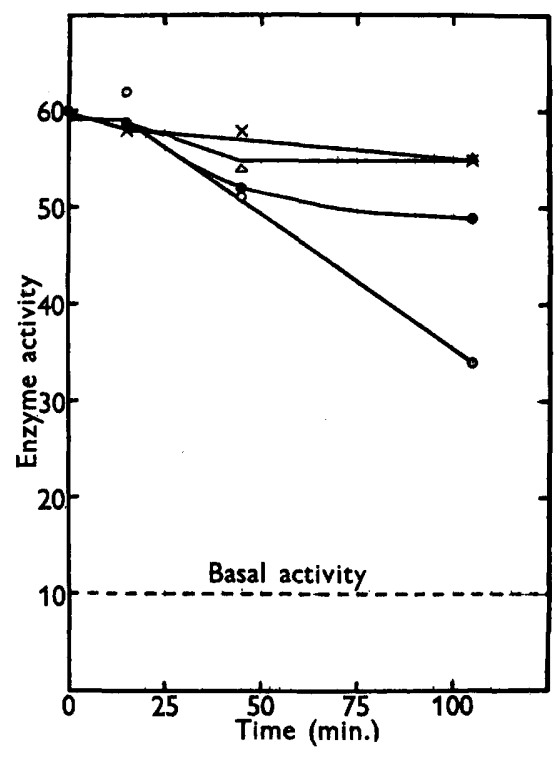

Fig. 7

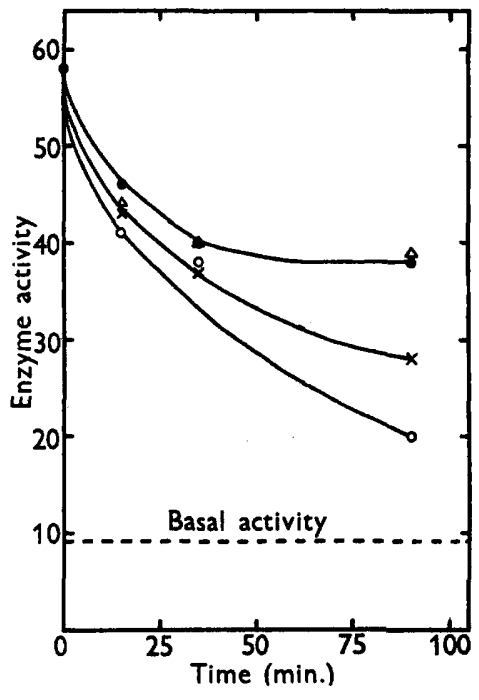

Fig. 8

Fig. 7. Effect of cadaverine on rate of de-adaptation. Adapted cells were washed and incubated as follows: - $-1 \%$ glucose; $x-x$, cadaverine $\left(10^{-4} \mathrm{M}\right) ; 0-0$, glucose + cadaverine; $\triangle-\triangle$, glucose + cadaverine $+\mathrm{NaN}_{3}\left(10^{-3} \mathrm{M}\right)$. Activity measured on intact cells.

Fig. 8. Effect of cadaverine, putrescine and histamine on rate of de-adaptation. Adapted cells were washed and incubated as follows: - $-1 \%$ glucose (control); $0-0$, glucose + cadaverine $\left(5 \times 10^{-4} \mathrm{M}\right) ; \times-\times$, glucose + putrescine $\left(5 \times 10^{-4} \mathrm{M}\right) ; \triangle-\triangle$, glucose + histamine $\left(5 \times 10^{-4} M\right)$. Activity measured on intact cells. 


\section{DISCUSSION}

It will be of interest to consider, first, the induced synthesis of lysine decarboxylase from the point of view of its rate of formation. In general, the curve of rate of synthesis of an induced enzyme might have the following different forms depending on the experimental conditions (see Mandelstam, 1952):

(a) Exponential-when the action of the induced enzyme on its substrate provides energy or material for the formation of more enzyme, that is, when the induced enzyme is not formed under what Monod \& Cohn (1952) have called conditions of 'gratuity'. Similarly, an exponential rate would be expected when the cells are growing in the presence of the inducer.

(b) Linear-when the enzyme is produced under conditions of 'gratuity' from a relatively large pool of material.

(c) Falling-when the pool of material is restricted.

The linear rate of appearance of lysine decarboxylase is therefore an indication-though not a proof-that the enzyme is being produced in conditions of 'gratuity' and, presumably, from a pool of material which is large relative to the amount of enzyme synthesized. With regard to the lag period found in the aerobic, but not in the anaerobic, experiments no definite explanation has been found for the phenomenon. The lag usually lasted for about $10 \mathrm{~min}$., but was often shorter and occasionally absent altogether. It can, perhaps, be ascribed to the retarded diffusion of lysine into the cell under aerobic conditions.

Considering, now, the adaptive behaviour of the intact cells, rather than their apo-enzyme content, it seems that the activity found at any one time is the resultant of two opposite processes: (i) an adaptive process caused by lysine; (ii) a de-adaptive process caused by cadaverine. The latter only becomes manifest when the concentration of lysine in the medium is no longer sufficient to stabilize the decarboxylase system. It was found, in experiments not quoted here, that, by adding small amounts of lysine at suitable intervals, adaptation and de-adaptation could be made to occur repeatedly.

The de-adaptation is apparently due to loss of pyridoxal phosphate, since the apo-enzyme is quite stable. A possible explanation seemed to be the induced formation of an enzyme which oxidizes cadaverine, with consequent sharing of a limited amount of the co-factor by the two enzymes. However, the evidence for this has not been found, since oxidation of cadaverine could not be demonstrated. The effect of cadaverine on pyridoxal phosphate has not been further investigated, and it is still possible that another enzyme is being induced which appropriates some of the pyridoxal phosphate. Alternatively, the presence of cadaverine may lead to an actual destructive loss of pyridoxal phosphate unless lysine is present to stabilize the decarboxylase. A stabilizing effect of substrate on pyridoxal phosphate has been found with ornithine decarboxylase in a Lactobacillus sp. (Rodwell, 1953).

As stated in the introduction, the object of these experiments was to seek confirmatory evidence for either the 'mass action' or the 'catalyst' theories of enzyme induction. It may be useful to consider to what extent the facts 
are in keeping with each of these concepts. Restricting the discussion to the synthesis of the apo-enzyme, the facts consistent with the 'mass action' theory are as follows: ( 1 ) the $\mathrm{pH}$ curves for enzyme induction and enzyme activity correspond closely, having similar peak values and similar form; (2) the rate of anaerobic synthesis is directly proportional to the degree of saturation of the enzyme by substrate. Both facts can be regarded as support for the idea that the concentration of the enzyme-substrate complex is the determining factor in the synthesis of the enzyme.

Against the theory is the fact that when enzyme production takes place aerobically, the rate is maximal even when the enzyme is largely unsaturated. The possibility that lysine is concentrated by the bacteria, so that the enzyme is saturated even at low external concentrations of substrate, has been examined and found to be untenable. Furthermore, it follows from the 'mass action' theory that, on removal of the substrate, the induced apo-enzyme should disappear at least as rapidly as it was formed; in fact, the apo-enzyme is stable in the absence of lysine. In view of these facts it is apparent that the 'mass action' theory does not provide an adequate description of the system and could be retained only by making a number of ad hoc assumptions.

From the standpoint of the 'catalyst' theory, the results of the aerobic induction experiments are consistent and so is the stability of the apo-enzyme in the absence of inducer. The anomalous facts are, first, the close correlation between the rate of anaerobic synthesis and the saturation of the enzyme, and secondly, the equally close correlation between the $\mathrm{pH}$ curves for enzyme induction and enzyme activity. To make the 'catalyst' theory fit these facts it would be necessary to postulate ad hoc properties either for the enzymesynthesizing mechanism or for the receptor. Thus, it could be assumed that induction is 'catalytic' but that, anaerobically, the enzyme-synthesizing mechanism depends on the decarboxylation of lysine for energy or material; that is, the enzyme is not being produced under conditions of 'gratuity'. This possibility has already been discussed and must be considered unlikely as it would entail an exponential rate of synthesis.

A further possibility is that lysine, as such, is required for the synthesis of new enzyme. If this were so, additional assumptions would have to be made to account for the $\mathrm{pH}$ curves, for the difference between aerobic and anaerobic induction by small amounts of lysine, and for the correlation between enzyme saturation and the anaerobic rate of synthesis. The assumptions that would have to be made are: (a) synthesis of enzyme is optimal at that $\mathrm{pH}$ at which the enzyme is most effective; $(b)$ anaerobically lysine is the limiting factor in enzyme synthesis but aerobically it is needed only in traces if at all; $(c)$ the enzymesynthesizing mechanism, anaerobically, has exactly the same affinity for lysine as the enzyme itself. While Gale's work on the amino acid decarboxylases (1940) has shown that the first of these assumptions is justifiable, the second and third are much less probable and would, in any case, be difficult to verify experimentally.

Alternatively, the 'catalyst' theory could be retained by making the following assumptions about the receptor. (a) Aerobically the receptor has 
a relatively high affinity for lysine so that it is saturated at a concentration where the enzyme is almost completely unsaturated; anaerobically the affinity falls to a lower order altogether and the receptor now has a saturation curve that is virtually the same as that of the enzyme. It would have to be assumed that this similarity is fortuitous. (b) Both aerobically and anaerobically the affinity of the receptor for lysine is affected by $\mathrm{pH}$ in the same way as that of the enzyme and, again, the agreement would have to be considered fortuitous.

The position therefore seems to be that both the 'mass action' and the 'catalyst' theories are in accordance with some of the experimental facts, but that neither provides a complete explanation.

I wish to thank Miss R. Coyle for invaluable technical assistance and I am indebted to Roche Products Ltd. for a generous gift of pyridoxal phosphate.

\section{REFERENCES}

Cohen, P. P. (1940). Transamination with purified enzyme preparations (transaminase). J. biol. Chem. 136, 565.

Dixon, M. (1953). The determination of enzyme inhibitor constants. Biochem. $J$. $55,171$.

Galat, A. (1947). An improved synthesis of DL-lysine. J. Amer. chem. Soc. 69, 86.

GaLE, E. F. (1940). The production of amines by bacteria. 1. The decarboxylation of amino-acids by strains of Bact. coli. Biochem. J. 34, 392.

GaLe, E. F. (1947). The assimilation of amino-acids by bacteria. 1. The passage of certain amino-acids across the cell wall and their concentration in the internal environment of Streptococcus faecalis. J. gen. Microbiol. $1,53$.

GAUDRY, R. (1948). The synthesis of DL- $\alpha$-amino- $\epsilon$-hydroxycaproic acid and a new synthesis of DL-lysine. Canad. J. Res. B, 26, 387.

McLaren, A. D. \& KNIGHT, C. A. (1951). Preparation and microbiological activity of an homolog of lysine. J. Amer. chem. Soc. 73, 4478.

Mandelstam, J. (1952). Studies in biochemical adaptation. The 'mass action' theory of enzyme adaptation. Biochem. $J .51,674$.

Mandelstam, J. \& Yudkin, J. (1952). Studies in biochemical adaptation. Some aspects of galactozymase production by yeast in relation to the 'mass action' theory of enzyme adaptation. Biochem. J. 51, 686.

MonoD, J. \& CoHN, M. (1952). La biosynthèse induite des enzymes (adaptation enzymatique). Advanc. Enzymol. 13, 67.

Monod, J., Cohen-Bazire, G. \& Cohn, M. (1951). Sur la biosynthèse de la $\beta$ galactosidase (lactase) chez Esch. coli. La specificité de l'induction. Biochim. biophys. Acta, 7, 585.

Neuberger, A. \& Sanger, F. (1943). Availability of acetyl derivatives of lysine for growth. Biochem. J. 37, 515.

Oesterlin, M. (1932). Über die Darstellung von Aminbasen aus Carbonsäuren mittels Stickstoffwasserstoffsäure. Z. angew. Chem. 45, 536.

Pollock, M. R. (1950). Penicillinase adaptation in $B$. cereus: adaptive enzyme formation in the absence of free substrate. Brit. J. exp. Path. 31, 739.

Rodwell, A. W. (1953). Factors affecting the activation of the ornithine decarboxylase of a strain of Lactobacillus. J. gen. Microbiol. 8, 238.

SANGer, F. (1946). The free amino group of gramicidin S. Biochem. J. 40, 261.

YudkIN, J. (1938). Enzyme variation in micro-organisms. Biol. Rev. 13, 93.

(Received 10 June 1954) 